УДК [331.3+331.5]:338.2331.5:364.2

DOI: https://doi.org/10.32782/2413-9971/2020-34-4

Богуш Л. Г. кандидат економічних наук, старший науковий співробітник, провідний науковий співробітник Інституту демографії та сочіальних досліджень імені М. В. Птухи Національної академії наук України

\title{
Bogush Larysa
}

PhD in Economics, Senior Research Scientist, Leading Researcher Ptoukha Institute for Demography and Social Studies of the National Academy of Sciences of Ukraine

\section{ОПЛАТА ПРАЦІ ЯК ОСНОВА КУПІВЕЛЬНОЇ СПРОМОЖНОСТІ НАСЕЛЕННЯ}

Анотація. У роботі досліджуються засади та підходи до забезпечення гідної оплати праці як вагомого чинника усталення темпів розвитку економіки України завдяки відтворенню та підвищенню купівельної спроможності населення, реалізації потенціалу цієї категорії щодо інвестування та диверсифікації національного господарства. Визначено основні недоліки в політиці та практиці оплати праці в Україні, що загострилися в умовах суспільно-економічної дестабілізації та прискорення інфляційних процесів. Проаналізовано якість нормативно-правового забезпечення системи оплати праці та купівельноспроможної мінімальної зарплати. Обгрунтування розмірів гідної оплати праці на основі державних соціальних стандартів і гарантій, що втілюють спектр загальносуспільних, суспільно необхідних та приватних потреб населення, кардинальне підвищення ефективності організаційно-економічного механізму регулювання системи оплати праці та ії купівельної спроможності сприятимуть розв'язанню нагальних та системних проблем у сфері усталення процесів забезпечення кадрами економіки України, реалізації стимулів і механізмів продуктивної зайнятості шляхом оптимізації вартості відтворення робочої сили.

Ключові слова: оплата праці, купівельна спроможність заробітної плати, соціальні стандарти і гарантії, прожитковий мінімум, мінімальна зарплата, державна соціально-економічна політика.

Вступ та постановка проблеми. Оплата праці $\epsilon$ важливою економічною категорією, що пов'язує суспільні інститути економіки, держави, соціального забезпечення, ринкові відносини та інституції самоорганізації населення (а отже, соціально-економічні системи, що їх представляють), формалізуючи їх цілі та завдання в життєдіяльності соціуму, визначаючи пріоритети, напрями та механізми функціонування.

У світі, де домінують нео- та постіндустріальні національні економіки, підприємницькі корпорації яких формують та кооперують у транснаціональних структурах, зумовлюючи глобалізацію світової економіки, склалися тісні взаємозв'язки між рівнем оплати праці, підходами до використання і відтворення людського та професійнокваліфікаційного потенціалу, фінансовими результатами господарювання на загальнодержавному й макрорегіональному рівнях.
Нагальність формування узгодженої стратегії розв'язання цих питань в Україні визначається усталеними недоліками і диспропорціями іï соціально-економічного розвитку, пом'якшення та усунення яких потребує диверсифікації національного господарства, відновлення й розвитку замкнутих циклів виробництв у його регіональних підсистемах, повноцінного відтворення, удосконалення кількісно-якісних характеристик трудоресурсного потенціалу і кадрового забезпечення спектру ланок та підприємств, оптимізації внутрішньодержавних і транскордонних трудових міграцій, що є основою для підвищення конкурентоспроможності вітчизняної продукції на зовнішніх ринках, переходу від ресурсно-сировинної і напівфабрикатної моделі експорту до розширення пропозиції готових, у т. ч. наукоємних та інноваційних, товарів і послуг, розгалуження сфери зайнятості, стабілізації соціально-економічної ситуації в регіонах і територіальних громадах. 
Вартість відтворення робочої сили, прийнятна на конкретному історичному етапі розвитку держави та суспільства, визначається потребами, стимулами і механізмами забезпечення кадрами національної економіки та їх продуктивної зайнятості, обгрунтовуючи розміри гідної оплати праці та купівельноспроможної мінімальної заробітної плати, а також їх фактичних номінальних та реальних величин.

Підходи до визначення рівня і розмірів оплати праці як чинника усталення темпів розвитку економіки України, забезпечення належної купівельної спроможності населення та реалізації потенціалу цієї категорії щодо інвестування й диверсифікації національного господарства має, насамперед, акумулюватися в процесі конкретизації соціальних стандартів і гарантій, удосконалення підходів до їх реалізації в методиках визначення, індексації мінімальної заробітної плати, дотримання зазначеної ключової гарантії суспільно прийнятної якості відтворення робочої сили в тарифних і безтарифних системах оплати праці.

Аналіз останніх досліджень і публікацій. Проблематика та нагальні пріоритети формування механізмів і регулювання процесів оплати праці як основи забезпечення суспільно прийнятної купівельної спроможності населення, запобігання трудовій бідності та маргіналізації зайнятих, відтворення сукупної робочої сили, нарощування інвестиційного потенціалу національного господарства, удосконалення діяльності із забезпечення його кадрами продовжують висвітлюватися у широкому спектрі фахових праць.

3'ясування соціально-економічних аспектів оплати праці, поточних проблем іiі формування і здійснення в Україні [1-4] дає змогу обгрунтовувати підходи до оцінки купівельної спроможності заробітної плати, розробляти пов'язані із цією функцією напрями оптимізації оплати праці $[2 ; 5 ; 6]$. При цьому пропонуються актуальні новації в збалансуванні базових компонентів соціальних стандартів і гарантій з урахуванням вагомої ролі оплати праці в їх формуванні та реалізації [7-10].

Водночас подальшої систематизації та обгрунтування потребують підходи до оптимізації механізмів і процесів оплати праці в Україні завдяки узгодженому вдосконаленню як відповідної нормативно-правової бази, так і короткострокових та довготривалих пріоритетів профільної державної політики.

Мета статті. Зважаючи на системні суспільно-економічні проблеми із розробкою та реалізацією стандартів і механізмів оплати праці в Україні, що потужно впливають на кількісно-якісні параметри відтворення і реалізації трудоресурсного потенціалу, забезпечення кадрами національного господарства, розвиток і спеціалізацію його територіальних підсистем, подальшого дослідження потребують підходи до збалансування нормативних засад оплати праці та впровадження іiї гідних розмірів та кардинального підвищення ефективності організаційно-економічного механізму регулювання іiї купівельної спроможності.

Результати дослідження. У нормування підходів до визначення суспільно прийнятного (гідного) рівня оплати праці, а отже, купівельної спроможності заробітної плати, починаючи з ії мінімальних величин, визначається передусім розумінням параметрів і вартості відтворення робочої сили (простого, у межах фізіологічних та інших життєво необхідних потреб, або розширеного, з урахуванням соціального компоненту відтворення та вдосконалення трудового потенціалу, що передбачає задоволення ширших пізнавальних, а також культурно-освітніх та освітньо-дозвіллєвих, рекреаційних - медичних і оздоровчих потреб).
Отже, купівельна спроможність заробітної плати грунтується на прийнятому в державі (тобто втіленому в нормативно-правовій базі) трактуванні фізіологічного і соціального прожиткових мінімумів, зміст яких, своєю чергою, визначається, зважаючи на еволюцію поглядів певного соціуму щодо базових (життєвих), суспільно необхідних та приватних потреб, а також відповідних товарів і послуг.

До переліку показників, вагомих для оцінки рівня та динаміки купівельної спроможності заробітної плати та доходів населення, нині прийнято включати не лише витрати на продукти харчування, так звані обов'язкові витрати (на послуги житлово-комунальні й громадського транспорту), непродовольчі товари першої необхідності, базові товари тривалого використання (насамперед побутову, комп'ютерну техніку, засоби зв'язку індивідуального користування), базові культурно-освітні, медичні, рекреаційні послуги, а й виплати по кредитах і позиках, а також витрати на пальне для приватного автотранспорту.

Характеризуючи зміст і зв'язок категорій державних соціальних стандартів та прожиткового мінімуму, слід зауважити на відмінностях у трактовці їх взаємозалежності в базових нормативно-правових актах України. Якщо в Законі від 05.10.2000 № 2017-III «Про державні соціальні стандарти та державні соціальні гарантії» (ст. 1) прожитковий мінімум апріорі має враховувати певні затверджені соціальні норми, раціональні та мінімальні нормативи споживання, то, згідно із Законом від 15.07.1999 № 966-XIV «Про прожитковий мінімум» (ст. 2), саме ця вартісна величина є основою державних соціальних стандартів обслуговування та забезпечення, оскільки повинна застосовуватися для їх визначення.

Важливим аспектом недостатньо ефективної діяльності вітчизняних органів влади з опрацювання методики обчислення прожиткового мінімуму, заснованої на реалізації державних соціальних стандартів (як основи для визначення величин мінімальної оплати праці та соціальних виплат), є проблема формування та належного впровадження Державного класифікатора соціальних стандартів і нормативів, розроблення якого було започатковане на виконання ст. 27 Закону «Про державні соціальні стандарти та державні соціальні гарантії», у т. ч. передбачаючи обгрунтування їх переліку та кількісно-якісних характеристик, диференційованих за соціально-демографічними ознаками. Указаний Державний класифікатор, із розробок міністерств і відомств зведений на базі Міністерства соціальної політики та затверджений його Наказом від 17.06.2002 № 293, досі не набув статусу державних стандартів України та продовжує періодично доопрацьовуватися, як наслідок, не маючи обов'язкового для виконання характеру та фактично залишаючись складовою частиною державної системи класифікації і кодування соціально-економічної інформації.

Отже, прийнята в Україні методика розрахунку прожиткового мінімуму доволі слабко враховує зміст власне соціального компоненту цього поняття (як вартісного відображення кола потреб у культурно-освітніх, медичних, рекреаційних та інших товарах і послугах, споживання яких забезпечує належну - таку, що відповідає Конституції й решті нормативно-правових актів - якість соціального відтворення індивідів та соціальних груп, суспільства у цілому), оскільки, зважаючи на обсяг формально доступних ресурсів, концентрується передусім на відшкодуванні мінімальної вартості товарів і послуг, необхідних для фізичного виживання людини. Рівень бідності, що визначається подібним прожитковим мінімумом, відповідає лише рівню фізичного виживання (тобто 
абсолютної бідності), змушуючи орієнтиром вітчизняної соціальної політики вважати не стільки забезпечення гідних умов життєдіяльності та якості життя населення, скільки досягнення рівня соціальної (або відносної) бідності. Саме межі останньої прийнято вважати граничним індикатором соціальної безпеки процесу збідніння, коли ще реальна ефективна підтримка відповідних верств, яка може гарантувати прийнятний (достатньо безпечний) рівень солідарності й злагоди у соціумі.

За новітній період розвитку незалежної України відбулися суттєві зміни в гарантіях з оплати праці. Мінімальна заробітна плата тривалий час була нижча за законодавчо встановлений прожитковий мінімум і лише в 2009 р. зрівнялася 3 ним, у 2017 р. - його перевищила (кардинальне підвищення рівня мінімальної зарплати стимулювалося, передусім, інфляцією, звуженням частини традиційних ринків збуту підприємств-експортерів, стрибками валютних курсів, а отже, загостренням потреби наповнення в цих умовах Пенсійного фонду та фондів обов'язкового соціального страхування). Згідно із законотворчими та урядовими ініціативами 2019-2020 рр. (зокрема, законопроєктом № 2720 від 13.01.2020 «Про внесення змін до деяких законодавчих актів України щодо створення передумов для підвищення прожиткового мінімуму», відкликаним 04.03.2020), прожитковий мінімум активно пропонують усунути 3 методик розрахунків мінімальної зарплати та низки соціальних виплат, що може негативно вплинути на оцінку реальних масштабів та перспектив подолання трудової бідності. Нині прожитковий мінімум фактично усунуто 3 активного застосування в методичних підходах до визначення рівня мінімальної зарплати, оскільки, згідно 3 поточною редакцією Закону «Про оплату праці» від 13.02.2020, мінімальна заробітна плата $\epsilon$ державною соціальною гарантією, що дорівнює встановленому законом мінімальному розміру оплати праці за виконану працівником місячну (годинну) норму праці (ст. 3). Отже, сфера використання категорії прожиткового мінімуму в поточній практиці обмежена визначенням низки соціальних виплат [7].

Водночас попри значне зростання в 2017-2018 рр. номінальних показників мінімальної заробітної плати і прожиткового мінімуму дослідження їх динаміки у переведенні у долари США та євро засвідчує, що розмір заробітної плати нині відповідає рівню 2011-2012 рр. Бюджет України 2018 р. передбачав погодинну оплату праці в розмірі 22,41 грн (або 68 євроцентів) проти 3,7 євро у Болгаpiï, 4,4 - у Румунії, 5,8 - у Литві, 6,0 - у Латвії, 15,6 - у Греції, 31 - у Німеччині, 34,9 - у Франції, 39,5 - у Данії, 40,4 - у Бельгії, 41,9 - у Швеції [1, с. 24].

У період із 2010 р. частка заробітної плати у структурі витрат на одиницю виробленої продукції в Україні послідовно скоротилася до 8-9\%, у країнах ЄС натомість, сягаючи 40-45\%. Якщо у розвинутих державах світу через заробітну плату відбувається оборот понад $60 \%$ ВВП, то в Україні - менше 30\%. Значною мірою завдяки цьому приблизно $60 \%$ фактично бідних припадає на родини, де працюють два члени сім’і, а принаймні 10 млн працюючих останнім часом із року в рік претендують на житловокомунальні субсидії [1, с. 24].

Натомість у США, наприклад, основою визначення розміру мінімальної заробітної плати є дані офіційної статистики щодо вартості життя сім'ї з чотирьох осіб (двоє дорослих і двоє дітей); відповідно до вимог Свропейської соціальної хартії, мінімальна заробітна плата має перевищувати 2,5 розміри прожиткового рівня [5, с. 32,34$]$.

Інституціалізація в Україні політики низького рівня мінімальної заробітної плати, усунення іiї зв’язку з купі- вельними потребами спектру соціальних груп є потужним чинником зростання несправедливої нерівності в доходах і добробуті населення, а отже, гальмування ефективного відтворення людського капіталу та людського розвитку загалом.

Погіршенню ситуації сприяють недоліки регулювання низки новацій у соціально-трудових відносинах, зокрема наслідки поширення їх нестандартних форм, а також новітніх систем оплати праці, як безтарифних (передбачають гарантовану мінімальну частину оплати праці та іiі непостійну частину, що безпосередньо залежить від кваліфікаційних характеристик і результатів роботи працівника), так і за погодинними тарифними ставками.

Джерелом проблем, зумовлених поширенням у вітчизняній економіці зазначених систем оплати праці, слід визнати нечіткість їх регламентації у вітчизняному законодавстві, що дає змогу роботодавцям економити на фонді оплати праці за рахунок найманого працівника за умови сплати ССВ із місячної мінімальної зарплати.

Згідно з Листом Мінсоцполітики від 20.03.2017 № 766/0/101-17/28, для працівників із погодинною оплатою має дотримуватися державна гарантія - мінімальна зарплата в погодинному (а не в місячному) розмірі. Отже, якщо працівник, якому встановлено погодинну тарифну ставку або праця оплачується за визначеними роботодавцем кваліфікаційними характеристиками і певними результатами роботи, виконав місячну норму праці, а розмір нарахованої зарплати виявився меншим за мінімальну місячну, то доплата до неї не проводиться [3]. Це суперечить вимогам базового документу в унормуванні погодинної оплати праці - п. 2 Методичних рекомендацій запровадження погодинної оплати праці та дотримання мінімальних годинних гарантій в оплаті праці, прийнятих Наказом Мінпраці та соцполітики від 16.04.1999 № 69, де зазначається, що зарплата не повинна бути меншою за розмір місячної мінімальної оплати праці за умови виконання місячної норми робочого часу, однак на практиці до уваги береться вищезгаданий пізніший лист Мінсоцполітики [3].

Своєю чергою, згідно 3 абз. 2 ч. 5 ст. 8 Закону «Про збір та облік єдиного внеску на загальнообов'язкове державне соціальне страхування» від 08.07.2010 № 2464, а також із Роз'ясненням ДФС від 13.04.2018 № 1549/ІПК/ 15-32-13-01-10, зарплата за місяць може бути меншою за розмір місячної мінімальної оплати праці, не зобов'язуючи доплачувати працівнику. При цьому контролюється лише обов'язковість відрахування $\mathrm{CCB}$ (якщо зарплата за місяць у системі погодинної оплати виявляється меншою за місячну мінімальну оплату праці в умовах виконання іiї місячної норми, то ЄСВ має нараховуватися не $з$ неї, а місячної мінімальної зарплати) [3].

Під нестандартними (або гнучкими) трудовими відносинами та відповідними формами зайнятості, що організуються на їх основі, розуміють практику найму суб'єктами господарювання (кадровими, рекрутинговими i т. п. агенціями) працівників для подальшого виконання ними роботи в іншого роботодавця. Указані форми зайнятості з організації позикової праці, які активно просуває бізнес-спільнота (насамперед 3 огляду на потребу зниження виробничих витрат, у т. ч. за рахунок скорочення штатних працівників, обмеження відповідальності за дотримання умов праці й якості трудових відносин), досі залишаються гостро дискусійним на рівні інститутів трипартизму та незадовільно регульованим феноменом світового і національних ринків праці.

У контексті дослідження засад і тенденцій оплати праці та іiї зв'язку з купівельною спроможністю населення, поши- 
ренням трудової бідності зайнятих серед основних недоліків практики позикової праці, що грунтуються на низькому рівні участі або й відстороненні працівника від визначення умов купівлі - продажу власної робочої сили на користь суб'єкта господарювання - посередника, слід зауважити:

- порушення трудового законодавства 3 боку як кадрових агенцій, так і організацій, що використовують позикову працю, які проявляються у відмінностях в умовах праці на однакових посадах певного підприємства цих працівників і штатно зайнятих (насамперед iii оплаті; режимі - понадурочно, у вихідні дні; доступності переходу до виконання інших трудових функцій та обов'язкового соціального страхування), а також у погіршенні гарантій зайнятості позикових працівників (укладання строкових трудових (або цивільно-правових) договорів замість постійних колективних трудових договорів з усіма прийнятими нормами захисту та пільгами, що можуть бути припинені в разі відмови підприємствакористувача від послуг агенції-посередника);

- відсутність перспектив підвищення рівня оплати праці у конкретного роботодавця-користувача, що розраховує іiі обсяг виходячи з окладу та фактично відпрацьованого часу; нестабільний трудовий режим позикових працівників, коли нижча (порівняно зі штатними працівниками підприємства-користувача) заробітна плата не відшкодовує вимушених (з ініціативи роботодавця) простоїв, понаднормових робіт та не компенсує небезпек виробничого середовища;

- необгрунтоване суттєве зниження або й ухиляння від витрат на навчання та підвищення кваліфікації персоналу на виробництві;

- часту практику істотного зниження обсягів або ухиляння від відрахувань до фондів соціального страхування, що мають витрачатися на виплати позиковим працівникам, які постраждали на виробництві, отримали профзахворювання, або їх сім'ям (у разі загибелі працівника), а також на виплату пенсій цій категорії зайнятих;

- загрози зниження рівня й якості життя, економічної та професійної деградації зайнятих позиковою працею (погіршення якості робочої сили через брак умов для самонавчання, розширення сфери досвіду та підвищення кваліфікації; скорочення платоспроможного попиту внаслідок нерівних умов оплати праці позикових працівників і штатно зайнятих; неритмічність надходжень до бюджетів домогосподарств позикових працівників, а отже, нестабільність їх витрат);

- розпливчатість механізму і методик розрахунку страхового стажу та пенсійних виплат за позикову найману працю, сумнівну доступність більш раннього виходу на пенсію для цієї категорії зайнятих;

- становлення схем порушення фіскального законодавства, заснованих на декларуванні для оподаткування лише контингенту штатних працівників, без урахування виведених за штат на засадах аутсорсингу, аутстаффінгу, тимчасового найму.

Важливим показником в оцінці тенденцій та пріоритетів підвищення купівельної спроможності заробітної плати $є$ рівень і динаміка співвідношення ii мінімальної та середньомісячної величин (індекс Кейтца). Уважається, що чим більший цей індекс, тим потужнішим $є$ вплив мінімальної заробітної плати на розподіл доходів, забезпечення соціальної солідарності та справедливості в країні. У країнах Західної Європи індекс Кейтца використовують як один з індикаторів ефективності заходів у рамках боротьби з бідністю, їх оцінки, обгрунтування та коригування. МОП рекомендує підтримувати цей індекс на рівні не нижче 50\%, урядові структури Свросоюзу - не нижче
60\%. Для порівняння: в Україні в останні два десятиріччя індекс Кейтца коливався здебільшого в межах 35-40\%, помітніше знижуючись у найбільш кризові 2008 р. - до майже 33\% та 2015-2016 pp. - приблизно до 31\%; лише кардинальне підвищення в 2017 р. розміру мінімальної зарплати сприяло його зростанню до $47 \%$ [5, с. 33].

Урахування бажаних параметрів зазначеного індексу дає змогу оцінити величину мінімальної зарплати, здатної позитивно вплинути на результати державного регулювання трудової бідності. Наприклад, якщо номінальна середньомісячна заробітна плата в 2019 р., за даними Держстату України, становила майже 10497 грн, то розмір мінімальної зарплати, ефективний у контексті належної якості заходів із відтворення робочої сили та стимулювання продуктивної зайнятості, мав сягати приблизно 5,2-6,3 тис грн за її фактичної місячної величини у 4173 грн (для порівняння: Законом від 25.08.2020 № 822-IX «Про внесення змін до Закону України «Про Державний бюджет України на 2020 рік» 3 01.09.2020 p. мінімальну зарплату підвищено лише до 5 тис грн).

Темпи зростання номінальної заробітної плати в Україні повсякчас перевищують темпи зростання реальної заробітної плати, а в кризові періоди спостерігалися суттєві розриви між номінальною та реальною заробітними платами, внаслідок чого попри кількісне зростання оплати праці спостерігається усталене системне незадоволення потреб принаймні простого відтворення людського потенціалу, незважаючи вже на необхідність підвищення якості його відтворення. Ключову роль у формуванні зазначеної негативної тенденції відіграють:

- прискорення темпів інфляції споживчих цін на тлі стагнації або подальшого погіршення економічної ситуації;

- висока вартість кредитів для населення (підвищення та доволі стрімкі коливання облікової ставки Національного банку, інших державних і комерційних фінансових установ, відповідні тенденції в динаміці валютних курсів, реалізація низки заходів щодо обмеження доступності валюти для населення і підприємств тощо).

Експертна оцінка рівня відповідності купівельної спроможності населення України отримуваній заробітній платі на основі його витрат на дизельне паливо засвідчила низький рівень купівельної спроможності та реальних доходів співгромадян, високий рівень інфляції та неспроможність широких верств на легальних засадах повноцінно задовольнити потреби у пересуванні на власному транспортному засобі, адже загальні місячні витрати на паливо становлять більше половини отримуваного доходу $(55,2 \%)$, тоді як у пересічній країні Свропи - не більше $10 \%$ (у т. ч. в Люксембурзі - 4,19\%, Ірландії - 6,25\%, Німеччині - 6,27\%), у США - 5,23\% [2].

Додавання до витрат на пальне ще й видатків на житлово-комунальні послуги (навіть без урахування вартості потреб у харчуванні та одязі) цілком обгрунтовує значну частку тіньової економіки в Україні, послідовне розширення масштабів та прискорення темпів транскордонної трудової міграції працездатного населення.

Водночас на тлі необхідності кардинального підвищення рівня мінімальної зарплати як ключового чинника поліпшення купівельної спроможності населення, підвищення рівня відтворення людського і, власне, професійнокваліфікаційного потенціалу нещодавній досвід України засвідчив, що необгрунтовано різке підвищення зазначеного показника без видимих ознак принаймні стабілізації економічної ситуації призводить до тінізації соціальнотрудових відносин (а саме поширення зловживань щодо заниження та приховування реальних доходів працівників iз метою пом'якшення податкового тягаря суб'єктів гос- 
подарювання), збільшення безробіття, зростання споживчих цін, зовнішнього та внутрішнього боргу, а отже, до зниження купівельної спроможності формально і неформально зайнятих співгромадян. Так, згідно з висновками фахівців Національного бюро економічних досліджень США, зробленими на вивченні досвіду 14 країн, підвищення мінімальної зарплати лише на 4-5 дол. США призводить до скорочення робочих місць на підприємстві на $2 \%[2 ; 6$, c. 8$]$.

Висновки. Зважаючи на роль гарантування гідної оплати праці як чинника стабілізації та прискорення темпів економічного розвитку, підвищення ефективності механізмів якісного відтворення робочої сили, а також забезпечення суспільної злагоди, відповідні заходи мають отримати статус наскрізних довготривалих пріоритетів державної соціально-економічної та інвестиційної політики.

Загалом чинники унормування гідної оплати праці та купівельноспроможної мінімальної заробітної плати відіграють ключову роль в оптимізації параметрів і тенденцій забезпечення кадрами економіки України, у т. ч. через безпосередню фінансову мотивацію роботодавців (адміністрації державних підприємств, підприємців інших форм власності) до поліпшення умов і якості відтворення трудового потенціалу зайнятих.

Методичні підходи до дослідження та забезпечення реальної купівельної спроможності заробітної плати доходів населення загалом базуються на врахуванні якісних і кількісних характеристик купівельних потреб населення, диверсифікованих у розрізі життєво й суспільно необхідних товарів і послуг та агрегованих за віковими категоріями.

Серед нагальних пріоритетів підвищення рівня оплати праці в Україні та кардинального посилення ролі цієї складової частини доходів населення в ефективному відтворенні конкурентоспроможної робочої сили слід, зокрема, відзначити:

- сприяння послідовному зростанню частки заробітної плати в структурі витрат на виробництво продукції за рахунок: фіскального стимулювання та надання преференцій роботодавцям і виробництвам, які реалізують подібні заходи, щодо участі в державних закупівлях, проєктах у рамках партнерства держави і приватного сектору (у т. ч. на концесійних засадах), тендерних процедурах приватизації і реприватизації спектру економічних активів; реалізації державних програм лобіювання інтересів соціально відповідального національного виробника на зовнішніх ринках товарів і послуг;

- посилення перехресного контролю над виконанням зобов'язань 3 виплати мінімальної заробітної плати (як базової державної соціальної гарантії) в рамках систем безтарифної і погодинної оплати праці зусиллями постійних і тимчасових комісій Кабінету Міністрів, загальнодержавних і регіональних фіскальних структур та інспекцій праці;

- упровадження обгрунтованої методики узгодження мінімальної заробітної плати, прожиткового мінімуму, решти прив'язаних до них базових соціальних стандартів у напрямах реалізації основоположних принципів соціальної держави (а саме створення умов для: забезпечення гідного життя працюючих і їх сімей силами самих зайнятих; підвищення ефективності механізмів соціальної інклюзії та запобігання маргіналізації; вирівнювання стартових умов виходу та реалізації особистісного потенціалу на ринку праці), а також зміцнення конкурентоспроможного потенціалу диверсифікації вітчизняного господарства й усталення темпів економічного зростання.
Водночас з оптимізацією процесів інвестування (зокрема, територіальних і галузевих інвестиційних потоків) та диверсифікації національної економіки, удосконаленням державних механізмів лобіювання на зовнішніх ринках інтересів національного виробника вагомими чинниками кардинального поліпшення національної політики України у сфері оплати праці $є$ :

- оптимізація базових чинників соціальної і територіальної мобільності (грунтується на суспільно достатньому рівні доходів громадян, реалізації заходів державної політики із саморегулювання регіональних диспропорцій за рахунок розвитку територій з особливими режимами господарювання та інноваційної інфраструктури, цільового створення нових робочих місць, сприяння місцевим програмам залучення й побутового облаштування необхідної робочої сили);

- «активізація» населення (засобами стимулювання підприємництва, самозайнятості та інноваційної активності суб'єктів господарювання, легалізації транскордонних та міжрегіональних трудових міграцій, удосконалення професійно-кваліфікаційного потенціалу трудових ресурсів згідно з потребами впровадження модерного технологічного укладу економіки);

- підвищення рівня конкурентності вітчизняної соціально-економічної політики збереження та продуктивного використання національного трудового потенціалу порівняно $з$ політикою країн, що приймають українських трудових мігрантів.

Отже, серед повсякчас (як у ближчій, так і в довготривалій перспективі) актуальних пріоритетів регулювання рівня оплати праці та купівельної спроможності формально і неформально зайнятих в Україні слід відзначити:

- подальше підвищення рівня мінімальної заробітної плати, дотримання прийнятних нормативів оплати праці у відповідних безтарифних системах;

- оновлення змістового наповнення прожиткового мінімуму з виділенням його фізіологічного та соціального компонентів; регулярний перегляд відповідних наборів продуктів харчування, непродовольчих товарів і послуг, що становлять прожитковий мінімум, а також стандартів їх споживання;

- реалізацію Державного класифікатора соціальних стандартів і нормативів у нормативно-правовому і ресурсному (фінансовому, матеріально-технічному, кадровому) забезпеченні процесів надання територіальній громаді суспільно необхідних послуг;

- обгрунтування пропозицій щодо оптимізації соціального діалогу та колективно-договірного регулювання трудових відносин, насамперед нестандартних; посилення механізмів захисту прав зайнятих на гідні умови, режим та оплату праці у разі фактичного вступу в трудові відносини, оформлені строковим трудовим договором або цивільно-правовим комерційним договором;

- контроль у сфері обмеження можливостей ухиляння роботодавців (як вітчизняних, так і зарубіжних компаній) від надання працівникам соціально-трудових гарантій, у т. ч. на підприємствах, що змінюють форму власності, власника, організаційні підходи до ведення основних та допоміжних видів господарювання;

- посилення контролю над діяльністю із заборони «зарплати в конвертах», упровадження ефективних адміністративних механізмів подолання практики внесення до трудових договорів і строкових контрактів вимоги щодо нерозголошення розміру оплати праці;

- подальшу оптимізацію підходів до оподаткування підприємств, які порівняно з іншими витрачають значні кошти на професійне навчання персоналу безпосередньо 
на виробництві та в спеціалізованих центрах професійної освіти, у т. ч. відомчих;

- запровадження методик відстеження практики формального зниження рівня оподаткування суб'єктів гос- подарювання внаслідок виведення частини працівників за штат (у тому числі за спрощеними схемами малого бізнесу), моніторинг і профілактику такої незаконної діяльності.

Список використаних джерел:

1. Балан О.Д., Савченко Ю.К. Оплата праці та її соціально-економічні аспекти. Агросвіт. 2018. № 10. С. $22-26$.

2. Мельник O.І., Болехівський О.Д., Лаврук І.Г. Проблеми заробітної плати в Україні та шляхи їх вирішення. Eфективна економіка. 2019. № 1. URL: http://www.economy.nayka.com.ua/?op=1\&z=6827 (дата звернення: 24.12.2020)

3. Онищенко В. Погодинна оплата праці 2020. Головбух. 28.09.2020. URL: https://www.golovbukh.ua/article/7724-pogodinnaoplata-prats-2020 (дата звернення: 24.12.2020).

4. Хаустова С.Б., Маринченко І.В. Проблеми заробітної плати в Україні та шляхи їх вирішення. Международный научный журнал. 2015. № 9. С. 159-163.

5. Кравчук А.О. Купівельна спроможність заробітної плати як основа фінансової стабільності держави. Фінансові дослідження. 2017. № 1 (2). С. 29-37.

6. Чирва Р. Від зарплати до зарплати. Профспілкові вісті. 2018. № 3 (933). С. 8-9.

7. Поскробок Ю. Зарплати, пенсії та соцвиплати по-новому: прожитковий мінімум з 2021 піднімуть. 24 канал. 5.11.2020. URL: https://economy.24tv.ua/prozhitkoviy-minimum-2021-ukrayina-zakonoproyekt n1351583 (дата звернення: 24.12.2020).

8. Як Україні досягти підвищення рівня реальних трудових доходів працюючих громадян? / В.М. Андрєєв та ін. Київ : Українська сторона Платформи громадянського суспільства Україна - EC, 2018. 51 c. URL: https:/www.civic-synergy.org.ua/ wp-content/uploads/2018/04/web_final_26_12_2017_labor-incomes_2017.pdf (дата звернення: 24.12.2020).

9. Жадько К.С., Стасюк А.В., Сімон А.П. Проблеми державного регулювання оплати праці в Україні. Інфраструктура ринку. 2017. Вип. 12. С. 185-189.

10. Григор'єва О.В., Шуткіна І.С. Застосування сучасних систем оплати праці на підприємствах України. Глобальні та національні проблеми економіки. 2015. Вип. 5. С. 764-767. URL: http://global-national.in.ua/archive/5-2015/156.pdf (дата 3вернення: 24.12.2020).

1. Balan O.D., Savchenko Yu.K. (2018) Oplata pratsi ta yii sotsialno-ekonomichni aspekty [Remuneration and its socio-economic aspects]. Ahrosvit, no. 10, pp. 22-26.

2. Mel'nyk O.I. Bolekhivs'kyj O.D., Lavruk I.H. (2019) Problemy zarobitnoi platy v Ukraini ta shliakhy yikh vyrishennia [Wage problems in Ukraine and ways of their solution]. Efektyvna ekonomika, (electronic journal), no. 1. Available at: http://www.economy.nayka.com.ua/?op=1\&z=6827 (accessed 24 December 2020).

3. Onyschenko V. (2020) Pohodynna oplata pratsi 2020 [The hourly wage in 2020]. Holovbukh, (electronic journal), 28.09.2020. Available at: https://www.golovbukh.ua/article/7724-pogodinna-oplata-prats-2020 (accessed 24 December 2020).

4. Khaustova Ye.B., Marynchenko I.V. (2015) Problemy zarobitnoi platy v Ukraini ta shliakhy yikh vyrishennia [Problems of wages in Ukraine and ways of their solution]. Mezhdunarodnyy nauchnyy zhurnal, no. 9. pp. 159-163.

5. Kravchuk A.O. (2017) Kupivelna spromozhnist zarobitnoi platy yak osnova finansovoi stabilnosti derzhavy [Purchasing power of wages as a basis for financial stability of the state]. Finansovi doslidzhennia, no. 1 (2), pp. 29-37.

6. Chyrva R. (2018) Vid zarplaty do zarplaty [From paycheck to paycheck]. Profspilkovi visti, no. 3 (933). pp. 8-9.

7. Poskrobok Yu. (2020) Zarplaty, pensii ta sotsvyplaty po-novomu: prozhytkovyi minimum z 2021 pidnimut [Salaries, pensions and social benefits in a new way: the subsistence level will be raised since 2021]. 24 kanal, (electronic journal), 5.11.2020. Available at: https://economy.24tv.ua/prozhitkoviy-minimum-2021-ukrayina-zakonoproyekt n1351583 (accessed 24 December 2020).

8. Andrieiev V.M. , Ostapenko L.V., Makohoniuk S.L., Zhyvolup I.V. (2018) Yak Ukraini dosiahty pidvyshchennia rivnia realnykh trudovykh dokhodiv pratsiuiuchykh hromadian? [How can Ukraine achieve an increase in the level of working citizens' real labor incomes?] (electronic edition). Kyiv: Ukrainska storona Platformy hromadianskoho suspilstva Ukraina - YeS, 51 p. Available at: https://www.civic-synergy.org.ua/wp-content/uploads/2018/04/web_finallabor-incomes_2017.pdf (accessed 24 December 2020).

9. Zhadko K.S., Stasiuk A.V., Simon A.P. (2017) Problemy derzhavnoho rehuliuvannia oplaty pratsi v Ukraini [Problems of wages' state regulation in Ukraine]. Infrastruktura rynku, vol. 12, pp. 185-189.

10. Hryhorieva O.V., Shutkina I.S. (2015) Zastosuvannia suchasnykh system oplaty pratsi na pidpryiemstvakh Ukrainy [Application of modern remuneration systems at the Ukrainian enterprises]. Hlobalni ta natsionalni problemy ekonomiky, vol. 5. pp. 764-767. Available at: http://global-national.in.ua/archive/5-2015/156.pdf (accessed 24 December 2020).

\section{ОПЛАТА ТРУДА КАК ОСНОВА ПОКУПАТЕЛЬНОЙ СПОСОБНОСТИ НАСЕЛЕНИЯ}

Аннотация. В работе исследуются основы и подходы к обеспечению достойной оплаты труда как весомого фактора обеспечения устойчивых темпов развития экономики Украины благодаря воспроизводству и повышению покупательной способности населения, реализации потенциала этой категории в сфере инвестирования и диверсификации национального хозяйства. Определены основные недостатки в политике и практике оплаты труда в Украине, обострившиеся в условиях общественно-экономической дестабилизации и ускорения инфляционных процессов. Проанализировано качество нормативно-правовой базы системы оплаты труда и покупательной способной минимальной зарплаты. Обоснование размеров достойной оплаты труда на основе государственных социальных стандартов и гарантий, воплощающих спектр всеобщих, общественно необходимых и частных потребностей населения, кардинальное повышение эффективности организационно-экономического механизма регулирования системы оплаты труда и ее покупательной способности будут способствовать разрешению насущных и системных проблем в сфере налаживания устойчивых процессов обеспечения кадрами экономики Украины, реализации стимулов и механизмов продуктивной занятости путем оптимизации стоимости воспроизводства рабочей силы.

Ключевые слова: оплата труда, покупательная способность заработной платы, социальные стандарты и гарантии, прожиточный минимум, минимальная зарплата, государственная социально-экономическая политика. 


\section{REMUNERATION AS THE BASIS OF THE POPULATION PURCHASING POWER}

Summary. The paper examines the principles and approaches to ensuring decent wages as an important factor in stabilizing the pace of Ukraine's economic development through the reproduction and increase of the population' purchasing power, realization of this category's potential for the national economy' investment and diversification. Remuneration is an important economic category that connects the social institutions of economy, state, social protection, market relations and institutions of the population' self-organization (and hence the socio-economic systems that represent them); remuneration formalize goals and objectives of mentioned institutions in socium, define their priorities, directions and mechanisms of functioning. The main shortcomings in the remuneration' policy and practice in Ukraine, which have worsened in the context of socio-economic destabilization and inflation acceleration, are identified; the quality of normative and legal provision of the remuneration system and the minimum wage' purchasing is analyzed. Institutionalization of low minimum wages policy in Ukraine, elimination of its connection with the purchasing needs of a range of social groups are the powerful factors in the growth of unfair inequality in the population' income and welfare, the spread of labor poverty and employees' marginalization, and thus - in inhibit the effective reproduction of human capital and human development in general. Substantiation of decent wages on the basis of state social standards and guarantees that embody the range of the population' common public, socially necessary and private needs, a radical increase in the efficiency of organizational and economic mechanism for regulating the system of wages and their purchasing power will help to solve urgent and systemic problems of sustainable development of the Ukraine' economy staffing processes, the implementation of incentives and mechanisms for productive employment by optimizing the labor reproduction cost. There have been formulated urgent and long-term priorities for: improving Ukraine's national wages policy; drastic strengthening the role of this population' income component in the effective reproduction of a competitive workforce; increasing the level and quality of meeting the socially necessary needs of formally and informally employed.

Key words: remuneration, purchasing power of wages, social standards and guarantees, subsistence level, minimum wage, state socio-economic policy. 